Research Paper

\title{
An analysis of trend in production, consumption and trade of cotton in India
}

See end of the paper for authors' affiliations

Correspondence to :

\section{S. NIRANJAN}

Department of Agricultural

Economics, College of

Agriculture (U.A.S.)

VIJAYAPUR, KARNATAKA,

INDIA

Paper History :

Received : 21.02.2017;

Revised : 21.07.2017;

Accepted : 02.08.2017
Abstract : Cotton, which is called as white gold, is one of the most important fibre crops grown in India, known for its trade value than any other fibre crops like, jute and mesta. Cotton cultivation in India is a source of livelihood for a considerable share of the farming community. Besides, the king of textiles, provide employment through textile mills and spinning mills to people in many parts of the country. A positive trend could be observed in the area, production and yield of cotton over the years. In particular, the productivity led growth in production witnesses the development of research activities which provides high yielding varieties and suitable efficient resource utilization techniques. Though improvement in the cotton production could be realized, increased consumption has decreased the export quantity of cotton over the years. Ultimately, cotton imports have increased with a growth rate of 12 per cent per annum, in the last decade. Moreover, the import price of cotton is very much higher than the price at which it is exported. To sum up, necessary steps should be taken to stabilize the cotton market and prevention measures should be taken to protect the crops from pest damage and uncertain natural calamities to stabilize the market from price fluctuations.

Key Words : Analysis of trend, Production, Consumption, Trade of cotton

How To Cite This PAper : Niranjan, S., Balaganesh, G. and Jamaludheen, A. (2017). An analysis of trend in production, consumption and trade of cotton in India. Internat. Res. J. Agric. Eco. \& Stat., 8 (2) : 293-298, DOI : 10.15740/HAS/IRJAES/8.2/293-298. 